\title{
Reflections on the Body in Clive Barker’s “The Body Politic”
}

\author{
Folio Jessica \\ University of Reunion Island, Reunion Island, France
}

\begin{abstract}
The article aims at deciphering Clive Barker's multilayered short story “The Body Politic” inserted in the 4th book of Books of Blood (1984-1985). In this work, the British author presents the human body as literally a book which has to be opened, rediscovered; it is a terra incognita marked by the resurgence of repressed elements or by the sense of urgency of applying a new significance to this locus. The notion of rewriting is a leitmotiv in "The Body Politic” as Barker seems to redefine not merely the organic political metaphor but drapes this imagery with Gothic, biblical or psychoanalytic veils. Julia Kristeva's Powers of Horror (1982) is a cornerstone to apprehend the depiction of the body as the ultimate unknown. The narrative traps the reader into the paradoxical hypnotic delights of the Otherized, abjectified body.
\end{abstract}

Keywords: Clive Barker, the body, political philosophy, the Gothic, the bible, abjection, identity

\section{Introduction}

The British writer Clive Barker is widely known for the cinematographic interpretations made out of his short stories composing his Books of Blood collection (1984-1985): Rawhead Rex (1986), Candyman (1992), Lord of Illusions (1995) or The Midnight Meat Train (2008). The expression "body horror" is a beacon enlightening his work: the horror caused for the reader by a body made into a monstrous, gaping wound. The reflection intends to consider the depiction of the body as an undefinable and incomplete locus to consider the elements making it unproportionate, ungendered, a very affirmation of the negation of our stability in knowledge.

Clive Barker's Books of Blood set of intricate and disruptive short stories are weaved with the red thread of corporeal materiality. Indeed, the six books enhance the theme of the body draped with the veil of fragmentation, dismemberment or dislocation. In "The Body Politic", which is included in the 4th book, Barker magnifies the paradigm of the body and its progressive annihilation. The narrative stages an improbable situation: the rebellion of hands against the human body, in other words, the rebellion of the body against itself. The dissidence is launched by Charlie George's hands, depicted right from the beginning as conspiring at night:

Whenever he woke, Charlie George's hands stood still. (...) They'd wait then; until his eyes had flickered closed and his breathing become regular as clockwork, and they were certain he was sound asleep. Only then, when they knew consciousness was gone, would they dare to begin their secret lives again. (Barker, 1988, p. 1)

This quotation already highlights various crucial dichotomies between appearances and reality, manifest and latent, known and unknown elements or unity and separation.

The exploration of the bodily theme by the British author raises manifold issues. The title of the story "per

Folio Jessica, Ph. D., English Department, University of Reunion Island. 
se" is an invitation to embark on an ideological journey as the reader is aware that the concept of "the body politic" has been tackled by theoreticians of political philosophy ${ }^{1}$ (Strauss, 1959, p. 12). The notion of rewriting, remolding of traditional themes permeates the text and is also developed throughout a reference to the Gothic novel along with a stress on religious connotations, both tainted with a subversive hue. The tearing apart of the body is at the core of the narrative and is accompanied with an upsurge of fluid loss creating among the characters a mingling of the seemingly disconnected feelings of attraction and repulsion. Kristeva's analysis of abjection emerges, as an analytical tool, then obsessively lingers on the surface of the text and accounts for our ultimate psychoanalytic angle of approach in our quest for deciphering Barker's multilayered narrative. Each problematic blooming in Barker's work serves his redefinition of the body as a source of the unknown, of indeterminacy and sheds light on a questioning of identity itself.

\section{A Political Interpretation}

In its simplest terms, the expression "the body politic" metaphorically refers to a nation likened to the human body. Kantorowicz (1957) developed the King's visible and invisible bodies ${ }^{2}$ and showed that beyond his physical and mortal body, the king was a body politic. The expression "the body politic" evolved from a monarchial viewpoint to the embodiment of the people of a politically organized nation, the people being seen as one entity. Analyzing Barker's story in the light of every theoretician is here impossible. Our modest enterprise will mainly be threefold and will start by casting a Machiavellian light on the narrative to open the path to a critical reading. Machiavelli links the political status to the existence of a living organism composed of governing humors $^{3}$, desires, which ensure its state of balance. The "body politic" also implies an idea of revolt when those humors are in conflict. The revolt is presented as regenerative by Machiavel, as a necessary process for the body politic to come back at its beginning and to start anew: "not completely a return backward but an alteration towards the prior time and a way not only to recapture the anterior state, but to improve the beginning further by returning to it, in a sort of differential return to its origin” ${ }^{4}$. Machiavelli praises the alterations of Republics, for the renovation of institutions is a condition for a longer life; the capacity of renewal through a return to the beginning is an indicator of the power of a regime.

Considering the element of rebellion, it has to be stated that Barker's narrative is replete with revolutionary lexicon. Here are three instances: "slowly, cautiously, it seems Charlie's hands creep up out of the warmth of the bed and into the open air. (...) They clasp each other in greeting, like comrade-in-arms” (Barker, 1988, pp. 1-2).

\footnotetext{
1 "Political philosophy is the attempt truly to know both the nature of political things and the right, or the good, political order". (Strauss, 1959, p. 12). Barker certainly has in mind the theories of Plato in The Republic (380 B.C.), Aristotle in Nicomachean Ethics (350 B.C.) or Politics (350 B.C.), Thomas More in Utopia (1516), Machiavelli in Discourses on Livy (1531) or The Prince (1532), Francis Bacon's reflections on the perfect Republic in The New Atlantis (1624), Thomas Hobbes in The Leviathan (1651), Spinoza's defense of democracy in Theologico-Political Treatise (1670) or Rousseau in The Social Contract (1762). The author suggests the reading of D. G. Hale. The Body Politic: A political Metaphor In Renaissance English Literature (1971) or the critical overview of political philosophy for example in Strauss's and Cropsey's History of Political Philosophy (1987).

2 The state is seen as an exroissance of the King's body.

3 This organic analogy was the cornerstone of the theoretical discourse of Renaissance politics.

${ }^{4}$ This is the author's translation from the French: "pas tout à fait un retour en arrière mais une altération vers le temps d'avant et une façon non seulement de retrouver l'état antérieur, mais encore d'améliorer le commencement en revenant à lui en une sorte de retour différentiel à l'origine”. The image is that of a repeating cycle. Machiavelli gives the example of Rome that finds a new life and virtue for itself after its defeat facing the Gauls.
} 
“The revolution had begun” (Barker, 1988, p. 12). "It was the sole proof of life after the body: and somehow it must communicate that joyous fact to a many fellow slaves as it could. Very soon, the days of servitude would be over once and for all” (Barker, 1988, p. 13). The hands are first presented as apparently complying with George's will like slaves to their master whereas in reality they prepare for their freedom.

Charlie progressively loses all control over his hands which, in a climatic moment, kill his wife while he is asleep. The revolution is launched by Charlie's left hand and the plotting done at night is an indicator that hands are entities of free will whose humors are no longer in accordance with the rest of the body. Following Machiavel's theory, the hands are choleric and their desire for freedom disrupts the sovereign body. The hands are driven by the sole desire of being cut free from the rest of the body perceived as a tyrant who has to be dethroned. The use of force is justified to ruin the previous laws. As all city dwellers' hands cut themselves free, they form a new nation to overthrow the former existing order of the body ${ }^{5}$. They perceive their rebellion as regenerative, as a purgation of the former body politic leading to the establishment of a better, fairer order, an improvement of the anterior state.

Nevertheless, irony stems out for, when they are free, the hands seem to set up a new form of tyranny to which the human body is now subjected. They overthrow a dictatorship to establish another improbable regime led by Charlie George's right hand. Their cruelty echoes Machiavelli's vision that a prince had to use cruel means to establish his absolute power ${ }^{6}$. The rebellion engenders a vicious circle encompassing the body and its limbs. If political stability implies forbidding the hegemony of a value upon others, it is not achieved in Barker's text. The rebellion of the limbs does not offer a more stable political state but the death or the loss of rationality among the various characters who helplessly witness their hands take their autonomy. People are depicted as lunatics mutilating themselves: "they were in frenzies of self-mutilation, most of them already maimed beyond hope of mending. (...) Knives taken to wrists and forearm; blood in the air like rain” (Barker, 1988, p. 16). A character named Lillian has her own hands blind her, depriving her of two senses: sight and touch.

In Barker's world, the rebellion of the hands is presented as the beginning of the era of the superiority of the limbs over the body itself. Barker's new "body politic” parallels Rousseau's vision of a moral and collective body composed of as many members as voices in the assembly giving to the body its unity, its common self ${ }^{7}$. "As a body, we incorporate every member as an indivisible part of the whole” (Rousseau, 1978, p. 61). The hands are clearly gathered in one united nation. Just as Rousseau saw the body politic of the government as ineluctably being in conflict with the body of the sovereign, the hands take their independence from the body. Yet, in Barker's world, the situation is more than conflicting; the new nation set up by the hands is driven by the violent

\footnotetext{
${ }^{5}$ In the emphasized gathering of hands, one recognizes the notion coined by Aristotle that Man is by nature a political animal in the sense that, like some animal species, human beings gather in groups and make an effort to live together. This is the case of the hands. For Aristotle, Man is a rational and moral animal. Here, however, if the hands behave as political animals gifted with reason, they are deprived of any morality.

${ }^{6}$ Machiavelli justifies the intelligent use of force in the reknown 15th chapter of The Prince (1532): “Concerning Things for which Men, and Especially Princes, are Praised or Blamed”.

7 "In place of the individual person of each contracting party, this act of association creates an artifical and collective body composed of as many members as there are voters in the assembly, and by this same act that body acquires its unity, its common ego, its life and its will. The public persona thus formed by the union of all other persons was once called the city, and is now known as the republic or the body politic. In its passive role it is called the state, when it plays an active role it is the sovereign" (Rousseau, 1978, pp. 61-62).
} 
destruction of the sovereign body they are normally coerced to.

Rousseau (1978) asserts that only in civil society can men experience freedom at its fullest. The social contract he depicts is necessary for Man's passage from a "narrow stupid animal" in the state of nature to "a creature of intelligence and a man” (p. 65) in a political society. Barker seems to reverse Rousseau's vision. In a way, the severing of the hands illustrates their desire for freedom and their willingness to return to a state of nature independent from the body. For the hands, it is not conceivable to be ruled and free at the same time. Their behavior corresponds to the Roussean (1978) state of possession based on force, "opposed to that of "property (by definition, rightful possession) [which] comes into being only when law comes into being”. The hands are in a state of "natural liberty" (p. 65) as they are bound to an absence of limits. Their gathering in a nation of hands is not achieved through a contract or the formulation of any laws but through the perception of the leader as the Messiah integrated from hands to hands in an instinctive way.

The human body is no longer a unified persona because the rebellion of its very limbs destroys any rational landmarks. Man is no longer master of himself. The human body becomes an alien entity, losing its identity, while the hands, on the opposite, affirm their identity with official names as it is signaled by the use of the capital letters: Right and Left.

The new created nation is in fact a totalitarian state headed by Right with the other hands enslaved to its will which aims at destroying the human body. Barker's vision echoes Claude Lefort's analysis of the organized totalitarian system as requiring an "Other", "the malefic Other”, i.e., a representation of the enemy (Lefort, 1981). The relationship between the people as "the one" and the "Other" is defined as prophylactic, meaning that the enemy is viewed as a waste, a parasite to be eliminated. In Barker's story, the body is the malefic other left to decay by the hands.

Barker seems to partake in the theory which views fragmentation not as a sign of a discarded whole but as revealing the importance of each unit of the body. In the article "The dismembered body: Bodily fragmentation as a metaphor for political renewal”, Guldin (2002) rightly recalls Bakhtin’s approach to the grotesque and the organic metaphor of late medieval society:

The single organs, especially the belly, but also the nose, the female breasts and the sexual organs claim their independence trying to break away from the unity of the body. In this world turned upside-down the lower half of the body comes into its own right again symbolizing through this a rejection of the political and ideological hegemony of the ruling classes. (p. 224)

The imagery of dismemberment echoes the need for change in society. The single parts are not considered as lesser organs, at the very image of the hands in Barker's story. They are the precursors of the rebellion of the limbs since at the very end, a pair of legs appears to their owner, moving on their own, happy to be free. Barker envisions uncommon parts of the body (hands or legs) as setting themselves free. The rebellion affects both the upper and lower parts of the body and aims at overthrowing the hegemonic body.

The political approach to "The Body Politic" has the reader envision convergences and divergences with theories of political philosophy. The ubiquitous use of hands is an auxiliary in the notion of rewriting which is the cornerstone of his work and which is also significant in Barker's use of literary and biblical references. 


\section{An Intertextual Interpretation}

Barker seems to gothicize $^{8}$ the metaphor of the body politic. The body is monstrosized with the emphasis laid on corporeal dismemberment, defilement and the alienation of identity. Barker transposes the pursuit of the innocent heroine by a treacherous villain in the maze-like corridors of a gothic castle or abbey into a gloomy city where people are grotesquely ${ }^{9}$ chased by hands. The city itself is a locus of confinement where the only way-out is death. The morbid, aggressive, transgressive sexuality which suffuses Gothic tales is displaced in Barker's narrative; the assaults on the bodies by the hands can indeed be perceived in a sexual perspective. The death of the female character, Lillian, is characterized by violence, lust, domination, pleasure for the assailant and horror for the victim. "They were massed like crabs at the fish-mongers, glistening backs pressed close to each other, legs flicking and clicking as they gathered in ranks. (...) they began to advance upon her. (...) there were hands aplenty to catch her” (Barker, 1988, p. 21). Her intimacy is baffled by the compact cohort of hands; the tension revolving around the physical contact is slowly built up when her body is objectified, used and thrown away like a puppet: "as they tipped her outraged body into a ditch, her wig (...) came off” (Barker, 1988, p. 21). The adjective "outraged" emphasizes the theory of her abused body but the latter is grotesquified by the mentioning of the wig. The hands are likened to a deus-ex-machina pulling the strings of human life in a merciless manner.

The monstrosization of the body is additionally enlightened by the blurring of the frontier between rationality and irrationality along with the carnivalesque atmosphere omnipresent in the text. Barker assembles the tragic topic of the annihilated body with a ludicrous objectification of that body. The shattering of corporeal unity explains the instability running through the veins of the narrative. The multiplicity of meanings surging from the text transforms it into a palimpsest concealing different layers of interpretations.

The reader cannot but notice that the text is replete with parodical biblical references. Right is grotesquely presented as the new Messiah: "Charlie wanted to run, but his right hand was having none of it. These were its disciples, gathered here in such abundance, and they awaited its parables and its prophecies” (Barker, 1988, p. 30). Right gives a mission to Left: "I am the Messiah. Without me there will be nowhere to go. You must raise an army, then come and fetch me” (Barker, 1988, p. 3). Left is freed with a kitchen knife and leads other rebellious human hands in waiting for the arrival of the Messiah. Right is a parodic Messiah, advocating rebellion and dismemberment, destruction of the human body as opposed to love, peace and reconciliation. Left is empowered with the mission of spreading the desacralized holy word to the disciples, i.e., the other hands. The feeling of freedom felt by Left is exhilarating and assimilated to a resurrection: "it was like birth into another world" (Barker, 1988, p. 13). However, the separation from the human body does not equal the ascension to a quasi holy state but a puzzling redefinition of the body.

Exploring further explore forward the biblical undertones, the rebellion of the hands against the body is a reminder of the Jews' revolt against the King of Egypt; in Barker's text, the body is the king that has to be destroyed. Consequently, the hands' journey through town and their gathering in a hospital to await their messiah

\footnotetext{
${ }^{8}$ Theories on the Gothic novel abound. Maurice Lévy for instance historicized the originally English 17th century literary movement in Le roman gothique anglais: 1764-1824 (1995). He clarifies the recurrent tropes of this movement: a fascination for death, bodily decay, ruins, confinement, morbid sexuality, transgression, excess, a questioning of identity, madness or dreams.

9 The grotesque is perceived perceive the grotesque in the Bakhtinian sense of the carnivalesque liberation of repressed elements and reversal of values. In Rabelais and his World, Bakhtin showed the importance of the tradition of the grotesque in medieval era and its link to the body seen in a hyperbolic way. The grotesque was regenerative mainly through laughing.
} 
grotesquify the biblical episode of the crossing of the Sinai desert to the Promised Land by the Hebrews and makes Left a Moses figure. Taken to a hospital after the severing of Left, Charlie is hypnotically led to an old, dilapidated part of the hospital to attend the reunion of all free hands gathered in the branches of a tree. "The hands were everywhere, it seemed: hundreds of them, chattering away like a manual parliament as they debated their tactics” (Barker, 1988, p. 30). The confused, chaotic atmosphere prevailing at that moment likens the tree to a new tower of Babel, tower characterized in the bible as the metropolis of confusion. In keeping with the inordinate, destructive ambition of men to supplant God causing the blurring of language as God's punishment, Barker highlights the ideas of the hands' crushing ambition, the loss of unity of the body and the absence of a human form of language.

The decayed tree in the abandoned garden is also viewed as a parodic tree of knowledge: "the tree had borne two amazing kinds of fruit” (Barker, 1988, p. 30): a dead surgeon and the hands. The discovery of the forbidden fruit goes well beyond the result of Adam's and Eve's discovery of their nudity; here it leads to murder. If the separation from the body is perceived by the hands as a rebirth, the new nation they mean to create parodies any similarities to the biblical birth of Adam and Eve. Indeed, as Eve was created from Adam's hips, the hands literally come out of the human body but of their own will. Their sins of revenge, murder and lust for dominion are all directed towards the body.

The new nation is a patchwork of hands, at the very image of Barker's story and its combining of possible interpretations. The postmodern quality of Barker's text is highlighted by this notion of patchwork and by the absence of a unique meaning of the text ${ }^{10}$. The human body itself is revealed as suffering from the postmodern condition: the disintegration and deconstruction of social or spatial references, of identity and the absence of unity. The essence of the body is redefined since common theories are no longer valid. The upstaging of a new order by the hands implies the collapse of former meanings and the construction of new meanings and new interpretations. The death of the psychiatrist, Dr Jeudwine, blatantly seals the destruction of a previous analytic order and signals the psychoanalytic challenge that the rebellion of the hands constitute.

\section{A Psychoanalytic Interpretation}

The symbolic role played by the hands is pointed out by the psychiatrist, Dr. Jeudwine. Charlie's hands' rebellious scheme is made during his sleep, "when they knew consciousness was gone” (Barker, 1988, p. 1): It refers to the moment when the repressed desires are not curbed by the censorship agency, the superego, and can be let loose ${ }^{11}$. Jeudwine explains Charlie's sense of loss of control by the theory of the return of the repressed. Jeudwine stresses Charlie's incomplete mourning process for his father's death which occurred during his childhood. After the funeral, Charlie suffered from nightmares; he imagined for months his father's hands hitting on the coffin to be let free. The hands stand for "symbols of the paternal power" (Barker, 1988, p. 5); in that case, they are interpreted as a displaced phallic power, a reminder of the law of the father. The rebellious hands'

\footnotetext{
${ }^{10}$ We keep in mind Lyotard's The Postmodern Condition (1979). Lyotard stressed the absence of one precise meaning, one truth as opposed to the case of modern "metanarratives". In postmodern works, the descriptive or narrative elements are no longer stable and the range of their interpretation is wide. In Of Grammatology (1967), Derrida criticizes the notion of logocentrism: a form of rationalism that presupposes a presence, an idea, a meaning behind language and texts. Deconstruction implies that this logocentrism no longer applies; language, writing are submitted to instability.

${ }^{11}$ Freud has a ternary vision of human psyche. The Id corresponds to the instincts and operates on the pleasure principle. The Ego operates on the reality principle. The Superego controls the Id's impulses.
} 
attempt at taking control over the human body can be analyzed as a sign of their will to be the new domineering, partriarchal force. The action of severing which resembles a castrative act is not a reducing act but is presented as a necessary step to leave the Imaginary state and reach the Symbolic ${ }^{12}$.

For Jeudwine, the non-closure on a traumatic childhood event would account for the return of the repressed, that is Charlie's obsession with hands. However, as events progress, Dr Jeudwine eventually accepts that the psychoanalytic theory does not apply in the occurring circumstances. When he sees two hands rolling Charlie's cat's head in his patient's house, his sanity and beliefs in prior well-established knowledge are demolished. This is at the image of what Barker does in his narrative; our supposedly mastered landmarks are shattered by the collapse of what is a constituent of our essence, the body. Jeudwine's belief in Freud's theory is annihilated: "who would put their faith in the efficacy of Freud and the Holy Writ of Reason?” (Barker, 1988, p. 23). Even here, the parodic tone emerges as the fundamental Freudian theories used to explain the wanderings of the psyche no longer have a solid ground and are sprinkled with a biblical reference.

It is when Jeudwine states the blurring of limits between rationality and irrationality, when he declares the invalidity of his reasonable explanations that he is overcome and is suffocated by his own hands. Jeudwine's attempt at asserting meaning to the empowerment of the hands, at inserting the unsayable in the logos (speech), fails, hence his deadly silence. The processes of guilt or repression turn into a void and it is the very absence of meaning which becomes the new order. A manifest fact remains merely a fact and there lingers no latent analyzable elements. This magnification of an absence of meanings, of blanks signals "the body politic" as a postmodern microcosm, a locus of instability, of incompleteness. The blatant reality of the body and the impossibility to comprehend it is horrifying. This void which cannot be grasped by the logos is qualified as "the horror" (Barker, 1988, p. 30).

Barker even denies any significance to the tragic outcome of the story. Charlie sacrifices himself by jumping from the roof of the hospital he has been admitted in so that all the gathered hands die by following their Messiah. For Charlie, death is the only way-out since cohabitation is impossible. "It was another being, to which he, by some unfortunate quirk of anatomy, was attached. He would be delighted to be rid of it” (Barker, 1988, p. 29). There is no redemption in Charlie's act as the idea of sacrifice normally implies, but simply a search for liberation. "There was no significance to be discovered in it, merely the paraphernalia of a minor apocalypse” (Barker, 1988, p. 32). The tem "paraphernalia" tones down the disappearance of the rebellious hands and the significance that it could vehicle. The term "apocalypse" itself which refers to the destruction of a world and the birth of a new one is degraded by Barker with the use of the adjective "minor".

This collapse in meanings enlightens the questioning of the body and its inherent unity transgressed in the narrative. The text is replete with mutilated bodies, leaking wounds and bodily fluids. The emphasis on blood, wounds, mutilation highlights the monstrosization and the abjection of the body by its very limbs. The body is made "Other" by itself; it engenders repulsion and fascination ${ }^{13}$. The depiction of the body echoes Kristeva's theory on the powers of abjection as similarities to her approach exist in Barker's text and serve his purpose of the

\footnotetext{
${ }^{12}$ Lacan tried to uncover processes of the unconscious through language and its associations. If the Imaginary is related to identifications, the Symbolic is marked by language.

${ }_{13}$ The characters in the story undergo a quasi hypnotic revulsion when they realize their total absence of control over their own bodies.
} 
remolding of the body. In her theory, Kristeva focuses on the mother-child relationship. The child has to abject the mother to establish the boundary between the self and the other, to leave the semiotic stage (union with the mother) and enter the symbolic stage. The feminine is perceived as "Other" and the construction of the monstrous feminine constitutes the basis for the passage from maternal authority to the law of the father. The abjection process is classified under three categories: food (vomit, the skin of the surface of milk), bodily waste (excrement-urine, feces-severed body, corpses) and the feminine (menstrual blood, lactation). The corpse is an example of the abject for it "draws me towards a place where meaning collapses” (Kristeva, 1982, p. 2); it is an element that we recognize but which is also other. In Barker's narrative, the effect is magnified with the omnipresence of dead bodies and the severed hands have the same impact as the corpse; the body becomes an unknown known.

In Barker's story, the abject appears not as an expression of the monstrous feminine but of the monstrous body. In Barker's paradigm of excess, the bond between the child and the mother seems to be replaced by a link between the hands and the body. The latter can indeed be perceived as a motherly agency, breathing life into the hands. The hands rebel against the body: they literally spit it out by cutting themselves free, letting the original bodies empty themselves from their blood. Though the blood flowing out of the mutilated bodies is no menstrual blood or maternal milk, it is still a mark of abjection by the hands of the "Otherized" body. The hands appear to break the link that confined them in the semiotic to reach a form of symbolic independence; the term "form" is used since they blindly follow Right and do not have a unique will. The abject is "to be identified with what threatens life, and it must, therefore, be radically excluded from the place of the living subject. The abject, in other words, is all that the subject excludes in order to be what it is, to have the identity that it does" (Schneider, 2004, p. 177).

If the hands have their own identity, this questions the notion of identity itself. Barker suggests a new type of entity, literally a blank, "a vision of a future without the body” (Barker, 1988, p. 23). The rebellion of the limbs seems endless for, at the very end, a pair of legs appears to their owner, moving on their own: "how long before the next uprising? Minutes? Years?” (Barker, 1988, p. 33). The construction of the new self would be reached through separateness with the body itself when the body should be the sine qua non basis of any existing being. The drawings below originating from the author have a clarifying intent (see Figure 1):

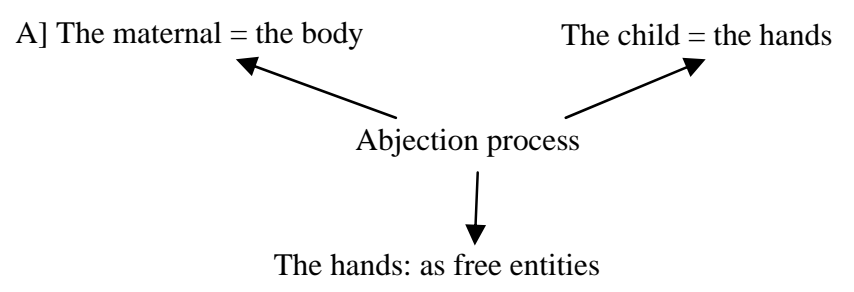

B] The body = self and oppressor

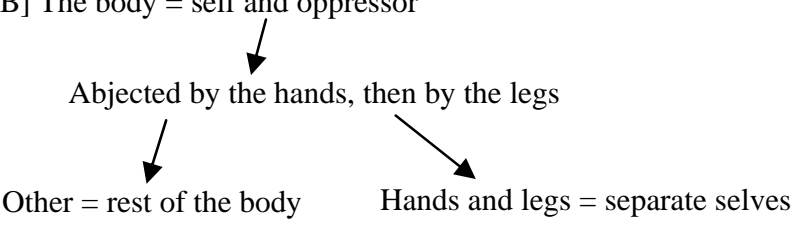

Figure 1. The stages of abjection. 
In Barker's text, the inherent link between each organ and the absence of scission are cast aside. The author provocatively stages a body-dominated society replaced by a limb-dominated society nevertheless driven by a unity of actions and effects. The status of the body is transcended and a dismembered self-literally a living oxymoron-is created. Barker undermines "the humanist notion of Man as a coherent and continuous [body]" (Hutcheon, 1988, p. 177). His redefining perspective stages the body as a living expression of the ultimate unfamiliar familiar ${ }^{14}$. It holds the same petrifying effect as Medusa's mask, being an auxiliary of "the terrifying horror of what which is absolutely other, unspeakable-pure chaos” (Vernant, 1991, p. 196). The readers cannot but empathize with the characters since they are led to reflect on the disintegration of their own bodies. Barker unveils the medusean pattern pervasively inscribed in the body and by so doing, he ensures an abreactic experience to his readers as well as the enduring success of his work.

\section{Conclusions}

The paper aims at deciphering Clive Barker's multilayered short story "The Body Politic" inserted in the 4th book of Books of Blood. In this work, the British author presents the human body as literally a book which has to be opened, rediscovered; it is a terra incognita marked by the resurgence of repressed elements or by the sense of urgency of applying a new significance to this locus. The notion of rewriting is a leitmotiv in "The Body Politic" as Barker seems to redefine not merely the organic political metaphor but drapes this imagery with Gothic, biblical or psychoanalytic veils. Julia Kristeva's Powers of Horror (1982) is a cornerstone to apprehend the depiction of the body as the ultimate unknown. The narrative traps the reader into the paradoxical hypnotic delights of the Otherized, abjectified body.

\section{References}

Barker, C. (1988). Books of blood: Second omnibus (pp. 1-33). London: Warner Books.

Derrida, J. (1976). Of grammatology. London: Johns Hopkins University Press.

Freud, S. (1919). The uncanny. (D. McLintock, Trans.). New York: Penguin.

Guldin. (2002). The dismembered body: Bodily fragmentation as a metaphor for political renewal. Retrieved from www.scielo.br/pdf/physis/v12n2/a03v12n2.pdf

Hutcheon, L. (1988). A poetics of postmodernism. New York: Routledge.

Kantorowicz, E. (1957). The king's two bodies: A study in mediaeval political theology. Princeton: Princeton University Press.

Kristeva, J. (1982). Powers of horror: An essay on abjection. New York: Columbia University Press.

Laplanche, J., \& Pontalis, J. B. (1974). The language of psychoanalysis. (D. Nicholson-Smith, Trans.). New York: Norton.

Lefort, C. (1994). L'invention démocratique: Les limites de la domination totalitaire (The democratic invention: The limits of totalitarian domination). Paris: Fayard.

Levy, M. (1995). Le roman gothique anglais: 1764-1824 (The English gothic novel: 1764-1824). Paris: Albin Michel.

Lyotard, J. F. (1984). The postmodern condition: A report on knowledge. Minneapolis: University of Minnesota Press.

Machiavelli, N. (1532). The prince. S. J. Milner, (Ed.). Indianapolis: Hackett Pub. Co..

Rousseau, J. J. (1762). The social contract. (M. Cranston, Trans.). Harmondsworth: Penguin Books.

Schneider, S. J. (Ed.). (2004). Horror film and psychoanalysis: Freud's worst nightmare. New York: Cambridge University Press. Sfez, G. (2000). Le corps politique (The body Politic). Retrieved from www.ac-nice.fr/massena/clubs/philo/pdf/corpspolitique.pdf

\footnotetext{
${ }^{14}$ We refer to Freud's notion of the uncanny defined as: "that species of the frightening that goes back to what was once well known and had long been familiar" (Freud, p. 150). Several issues are here at stake: A compulsion to repeat as well as the return of the commonly known that had been repressed. It is that repression that explains why the familiar has turned into the unfamiliar. The body is a supposedly mastered entity but Barker's transformation of the latter into an absolute other broadens the scale of our unconscious fears.
} 
Strauss, L. (1959). What is political philosophy? and other studies. Chicago: University of Chicago Press.

Vernant, J. P. (1991). Mortals and immortals: Collected essays. F. I. Zeitlin, (Ed.). Princeton: Princeton University Press. 